\title{
RESEARCHING CONSUMER HABITS REGARDING FOOD LABEL READING
}

\author{
Igor Trandafilović ${ }^{1}$,Zoran Milošević ${ }^{2}$, Slavoljub Vujović3
}

\section{Summary}

The research on the knowing of the significance and contents of the food product label as well as understanding the data on the label is presented in this paper. The research used the Pearson's chi-square test of homogeneity and Pearson's chi-square test of independence. The research was conducted on a representative sample of 598 respondents from 10 cities in the Republic of Serbia. Research results show that more than half of the respondents always or often read the label, then, that men and women have a similar relation to the frequency of reading the label and its contents. Respondents with special dietary regime frequently read the data on the label than with conventional regimens. Consumers that are more educated are more likely to read the label and know more about its contents. Respondents who know what the label should contain pay more attention to it.

Key words: food, consumer behavior, label, consumerism

JEL: $Q 13, D 12, M 31$

\section{Introduction}

Proper labeling of food is a fundamental precondition for realizing the rights of consumers, as defined by the Law on Consumer Protection. Paper indicates the basic guidelines and the objective of emphasis data on the label food products. Informing consumers about all-important characteristics of the food is a necessary precondition for the nation's health. Lack of information or misinformation on the labeling of food products can lead to unpredictable consequences and undermine the numerous rights of consumers as a social being.

1 Igor Trandafilović PhD, Associate Professor, John Naisbitt University, Faculty of Management Zaječar, Kraljevica bb, +381600599598, E-mail: tranfi@ptt.rs,

2 Zoran Milošević PhD, JP Pijaca Leskovac, Kralja Petra I bb, +381648973911, E-mail: miloseviczoran393@gmail.com

3 Slavoljub Vujović PhD, Economics Institute, Belgrade, Kralja Milana Street no. 16, +38163365101, E-mail: kelovic1967@yahoo.com

EP 2018 (65) $1(33-47)$ 
The subject of paper is the analysis of the contents and importance of the label on the food product, then, how often it is read, how much is believed in the accuracy of its data, and if it is an integral part of product quality. It examined and determined the dependence of above-mentioned parameters in relation to sex and age structure, acquired education and place of residence of the consumer.

The data were processed by means of causal statistics (mostly) and descriptive statistics (to a lesser degree). We used a representative sample of 598 respondents.

The importance of the paper, apart from scientific contribution, comes from its practical applicability, i.e., the research results point to the state in a very important area of consumer protection. Relation to the label on the food product implies a number of consumer rights guaranteed by the Law on Consumer Protection.

The transformation of Serbian national legislation in the process of country's accession to the European Union (EU) is a complex phenomenon and its scope and depth can significantly vary in different fields (Ćemalović, 2016).

As in other areas, it is necessary to harmonize regulations on the labeling of food products of the Republic of Serbia with the European Union. The legislative framework in Serbia governing this area:

- Law on Food Safety;

- Rules on food description, labeling and promoting;

- Rules on previously packaged products;

- Additional demands for labeling - vertical regulation).

The European Union with its common policies contributed to greater cooperation between member states in all aspects of agricultural production. Creating Economic Union, therefore, is fraught with the establishment of a developed concept of agricultural policy (Cvijanović, Simonović, Mihailović, 2011).

Labeling of food products in the European Union is governed inter alia by means of:

- Regulation (EU) No. 1169/2011 on the provision of food information to consumers;

- Regulation (EC) No. 1924/2006 on nutrition and health claims made on foods;

- Regulation (EC) 983/2009 on the authorisation and refusal of authorisation of certain health claims made on food and referring to the reduction of disease risk and to chidren's devolopment and health;

- Regulation(EU) No. 432/2012 establishing a list of permitted health claims made on foods, other than those referring to the reduction of disease risk and to children's development and health;

- The weight and measures (Packaged goods) Regulation SI 2006/659. 
U.S. Department of Health and Human Services - Food and Drug Administration and the Center for Food Safety and Applied Nutrition announced in January 2013. A Food Labeling Guide which are illustrated in detail all the characteristics of the declaration on the label of a food product.

Rules on food description, labeling and promoting in the Republic of Serbia (in Article 4) specifies that the "declaration must be done in a manner which does not deceive the final consumer, in particular with regard to:

- Characteristic staple food, especially its nature, identity, properties, composition, quantity, durability, origin and mode of production;

- Ascriptions characteristics and properties that food do not possess and emphasizing the characteristics of the food, which own some other foods of the same type."

Today, four factors compete in the ideological space of consumers: individual autonomy, social equality, consumer sovereignty and the dominance of corporations (Paul, 2010). Consumption and consumer behavior on the market are determined by a number of factors whose interaction led economic theorists to conclusions about the existence of regular phenomena which create supply and demand movements, and have influence on consumer behavior. In economic literature, among the most famous theoretical analyses of regularity in consumption, the following are mentioned: (1) Engel's laws, (2) Giffen's paradox, (3) Veblen effect, and (4) Kuznetsov phenomenon (Vujović et al., 2011).

Consumer protection organizations in Serbia have worked with varying degrees of success and in different circumstances. In recent years, however, there have been made significant efforts from the perspective of the legislative and legal regulations with the aim of harmonizing relations in this area (Božidarević, Salai, 2007). In this regard, starting from 2002, when the Serbian and Montenegrin Law on Consumer Protection was passed, significant actions aimed at improving consumer protection and its harmonization with European Union standards were taken in Serbia. According to the Law on Consumer Protection, Article 3, the basic rights of the consumer are as follows: meeting basic needs, safety, awareness, choice, voice of the consumer, compensation, consumer education, healthy environment (Simonović, 2006).

In that respect the indicated rights of consumers are similar to the regulations of other countries, so in general, there are no major differences. Differences arise in the practical implementation of legal guidelines. Countries with developed democracies insist more on the genuine realization of the specified consumer rights.

Even Payne Happer indicated in his paper that, regardless of the type of goods, the information on the label must be fully and accurately presented. It is necessary, in this regard, to standardize the information on the label (Payne, 1947).

Trade Law of the Republic of Serbia - Article 40 stipulates mandatory elements which the goods label must have in retail trade. These data are: the name and the type of goods, ingredients and quantity, as well as others in accordance with specific regulations and 
the nature of goods, and especially the data about the manufacturer, country of origin, date of production and expiry date, the importer, the quality (class), and a warning about the potential risk or harm of goods (Official Gazette of RS No. 53/2010). The label must be displayed on the goods i.e. the packaging or point of sale (in the case of the sale of bulk goods) prominently and legibly in the Serbian language. The label may also contain information in foreign languages.

According to the research conducted by Hieke and Newman (2015), consumers will make healthier food choices if the information on the label is emphasized more directly than in the case when the consumer needs to perform complex mathematical calculations.

Interesting is the research which shows a link between the power of a brand and the importance of label information indicating that the food is organic. The stronger and more famous the brand, the more the label of organic food loses its significance (Larceneux, Benoit, Renaudin, 2012). The label size can affect the perception of the product. A large label may make a smaller packaging seem larger than that which is actually smaller. In addition, consumers have more confidence in smaller rather than larger labels (Aydinoglu, Krishna, 2011).

The movement for the protection of consumer rights is called consumerism. Basically, consumerism is a set of activities undertaken by individuals, independent organizations, government agencies, businesses and other entities in order to protect consumers from unethical marketing practices (Maričić, 1999).

Despite the prescribed mandatory elements of the label, it often happens in practice that customers are misled by labels with semi-truthful data or data presented in a way which can lead consumers astray. In such cases, consumers may contact directly the authorized inspector or an association for the protection of consumers which will then institute proceedings for the protection of consumer rights and the sanction of unscrupulous traders.

\section{Materials and methods}

There are three main methods of collecting primary data on consumer behavior: an observational method, a testing method and an experimental method (Hanić, 2002, Trandafilović, 2008). During this fieldwork the testing method was applied.

The application of the methodology of field research on consumer attitudes in this study:

- In the field research a direct structured personal interview was used. The personal interview involves direct contact with the respondent;

- Field research in this paper uses the following sampling: the sample of consumers in 10 cities in Serbia without Kosovo and Metohija. The sample consisted of 598 consumers from: Vlasotince, Blace, New Belgrade, Pirot, Prokuplje, Šabac, Raška, Kruševac, Zrenjanin and Leskovac; 
- Answers were given in closed form. The questionnaire was filled out by circling one of the offered answers;

- SPSS and EDUSTAT statistical software packages were used in the calculation. The researchers used two approaches to data analysis:

a. Descriptive statistics (analysis of proportions);

b. Causal statistics (Pearson's chi-square test of homogeneity and Pearson's chi-square test of independence).

\section{Analysis of survey results}

The structure of respondents by sex, consists of a sample of interviewed consumers of $60.4 \%$ females and $39.6 \%$ males.

The age of the respondents is as follows: among women there are $15.56 \%$ of the respondents under 18 years of age; $17.50 \%$ between 18 and 30 years of age; $45.00 \%$ between 31 and 50 years of age and 21.94\% over 50 years of age. Among men there are $12.24 \%$ of the respondents under 18 years of age; $23.21 \%$ between 18 and 30 years of age; $36.28 \%$ between 31 and 50 years of age and $28.27 \%$ over 50 years of age.

Table 1. Structure of respondents by sex and place of residence

\begin{tabular}{|c|c|c|c|c|c|}
\hline & & & \multicolumn{2}{|c|}{ Sex } & \\
\hline & & & Male & Female & Total \\
\hline Place & Vlasotince & Number & 21 & 29 & 50 \\
\hline & & $\%$ & $42 \%$ & $58 \%$ & $100 \%$ \\
\hline & Blace & Number & 25 & 25 & 50 \\
\hline & & $\%$ & $50 \%$ & $50 \%$ & $100 \%$ \\
\hline & N.Beograd & Number & 43 & 56 & 99 \\
\hline & & $\%$ & $43.4 \%$ & $56.6 \%$ & $100 \%$ \\
\hline & Pirot & Number & 18 & 32 & 50 \\
\hline & & $\%$ & $36 \%$ & $64 \%$ & $100 \%$ \\
\hline & Prokuplje & Number & 21 & 28 & 49 \\
\hline & & $\%$ & $42.9 \%$ & $57.1 \%$ & $100 \%$ \\
\hline & Šabac & Number & 16 & 34 & 50 \\
\hline & & $\%$ & $32 \%$ & $68 \%$ & $100 \%$ \\
\hline & Raška & Number & 11 & 39 & 50 \\
\hline & Kruševac & Number & 15 & 35 & $100 \%$ \\
\hline & & $\%$ & $30 \%$ & $70 \%$ & $100 \%$ \\
\hline & & Number & 27 & 23 & 50 \\
\hline & & $\%$ & $54 \%$ & $46 \%$ & $100 \%$ \\
\hline & & & & & \\
\hline & & & $22 \%$ & $78 \%$ & 50 \\
\hline
\end{tabular}




\begin{tabular}{|c|c|c|c|c|c|}
\hline & Leskovac & Number & 40 & 60 & 100 \\
\hline & & $\%$ & $40 \%$ & $60 \%$ & $100 \%$ \\
\hline Total & & Number & 237 & 361 & 598 \\
\hline & & $\%$ & $39.6 \%$ & $60.4 \%$ & $100 \%$ \\
\hline
\end{tabular}

The level of education of respondents: Among respondents there were $11.0 \%$ who completed primary school; $44.4 \%$ with secondary education; $22.7 \%$ with a college degree; $21.9 \%$ with a university degree.

Graph 1. Structure of consumer-respondents with respect to the frequency of reading the label

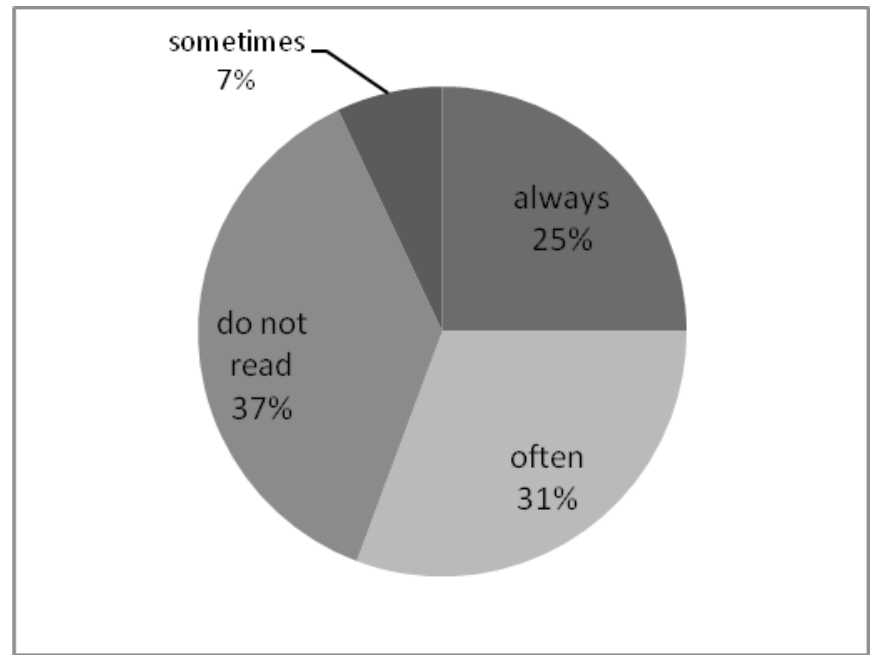

Graph 1. indicates that more than half of the respondents always or often read the label.

Sex of the respondents in relation to the frequency of reading the product label: $\left(\chi^{2} \mathrm{e}=\right.$ $6,172<\chi^{2} \mathrm{t}(\mathrm{DF}=3$ and 0.05$\left.)=7,817=>\mathrm{P}>0.05=>\mathrm{H} 0\right)$. Data analysis did not detect a statistically significant difference in these two groups. It can be concluded that: men and women have a similar relationship to the frequency of reading the label.

Age group with respect to the frequency of reading the label: $\left(\chi^{2} \mathrm{e}=39,833>\chi^{2} \mathrm{t}(\mathrm{DF}=9\right.$ and 0.05$)=16,919=>p<0.05 \Rightarrow$ H1 ). From presented results we can see that there is a significant statistical correlation between the age group and frequency of reading the label. Age groups of 31 and older, always and often read the label in relation to younger age groups - a test of homogeneity.

The level of education of consumers with respect to frequency of reading the label: $\left(\chi^{2} \mathrm{e}=40,585>\chi^{2} \mathrm{t}(\mathrm{DF}=9\right.$ and 0.05$\left.)=16,919 \Rightarrow \mathrm{p}<0.05 \Rightarrow \mathrm{H1}\right)$. From the data it is concluded that there is a significant statistical correlation between these two parameters. This means that the education of the respondents influences the frequency of reading the label. In other words with these data it is statistically confirmed that the higher the educational level of the consumer, the more he uses his right to information. 
Frequency of reading the label in relation to the place of residence of the consumer: $\left(\chi^{2} \mathrm{e}=60,090>\chi^{2} \mathrm{t}(\mathrm{DF}=27\right.$ and 0.05$\left.)=40,113=>\mathrm{p}<0.05=>\mathrm{H} 1\right)$. From the data it is evident that the relation to the frequency of reading the label varies according to the place of residence of the respondents.

A dietary regime in relation to frequency of reading the label: $\chi^{2} \mathrm{e}=48,474>\chi^{2} \mathrm{t}(\mathrm{DF}$ $=3$ and 0.05$)=7,817 \Rightarrow p<0.05=>\mathrm{H} 1)$. The data show that there is a significant statistical correlation between a dietary regime and the incidence of reading the label. Respondents with a special dietary regime more often read the data on the label than those with a conventional dietary regime.

Graph 2. Structure of the respondents' responses in relation to knowledge about the required contents of the label

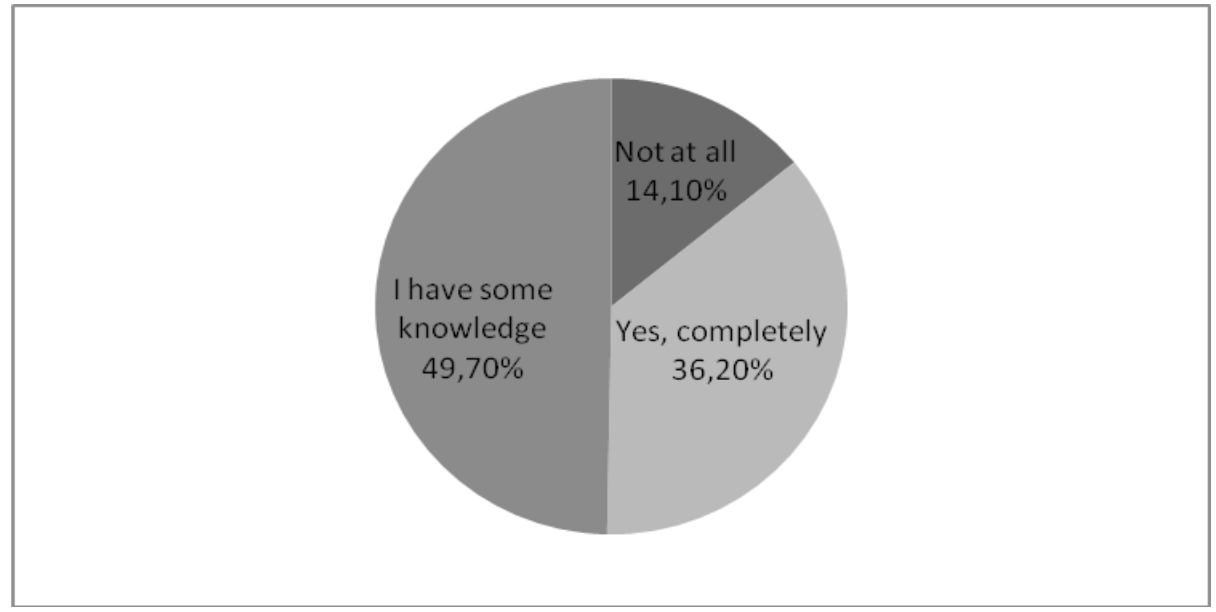

Graph 2. shows that the majority of respondents believe that they have some knowledge of what the label should contain.

Sex of the respondents in relation to what the label should contain: $\left(\chi^{2} \mathrm{e}=2,287<\chi^{2} \mathrm{t}\right.$ $(\mathrm{DF}=2$ and 0.05$)=5,991=>\mathrm{P}>0.05=>\mathrm{H} 0)$. Among members of different sexes there was not noticed any difference in the degree of how much they believe they know what the label should contain.

Age group in relation to knowledge of the contents of the label: $\left(\chi^{2} \mathrm{e}=12,926>\chi^{2} \mathrm{t}(\mathrm{DF}\right.$ $=6$ and 0.05$)=12,592=>p<0.05=>$ H1). The data show that there is a significant statistical correlation between age group and knowledge of what the label should contain. Respondents with over 30 years of age have a higher level of knowledge of the contents of the label.

The level of education of consumers in relation to the knowledge of what the label should contain: $\left(\chi^{2} \mathrm{e}=28,258>\chi^{2} \mathrm{t}(\mathrm{DF}=6\right.$ and 0.05$\left.)=12,592=>\mathrm{p}<0.05=>\mathrm{H} 1\right)$. The data show that there is a significant statistical correlation between the level of education of respondents and knowledge of what the label should contain. Educated respondents have more information. 
Knowledge of what the label should contain in relation to the residence of the consumer: $\left(\chi^{2} \mathrm{e}=42,787>\chi^{2} \mathrm{t}(\mathrm{DF}=18\right.$ and 0.05$\left.)=28,869 \Rightarrow \mathrm{p}<0.05=>\mathrm{H} 1\right)$. From the data it can be seen that the relation to knowledge of what the label should contain varies according to place of residence of the respondents.

A dietary regime in relation to knowledge of what the label should contain: $\left(\chi^{2} \mathrm{e}=\right.$ $13,175>\chi^{2} \mathrm{t}(\mathrm{DF}=2$ and 0.05$)=5,991=>\mathrm{p}<0.05=>$ H1. From the data it can be seen that there is a significant statistical correlation between a dietary regime and knowledge of what the label should contain. Respondents with a special dietary regime have more knowledge of what the label should contain compared to those with a conventional dietary regime.

Graph 3. Is proper labelling an integral part of product quality?

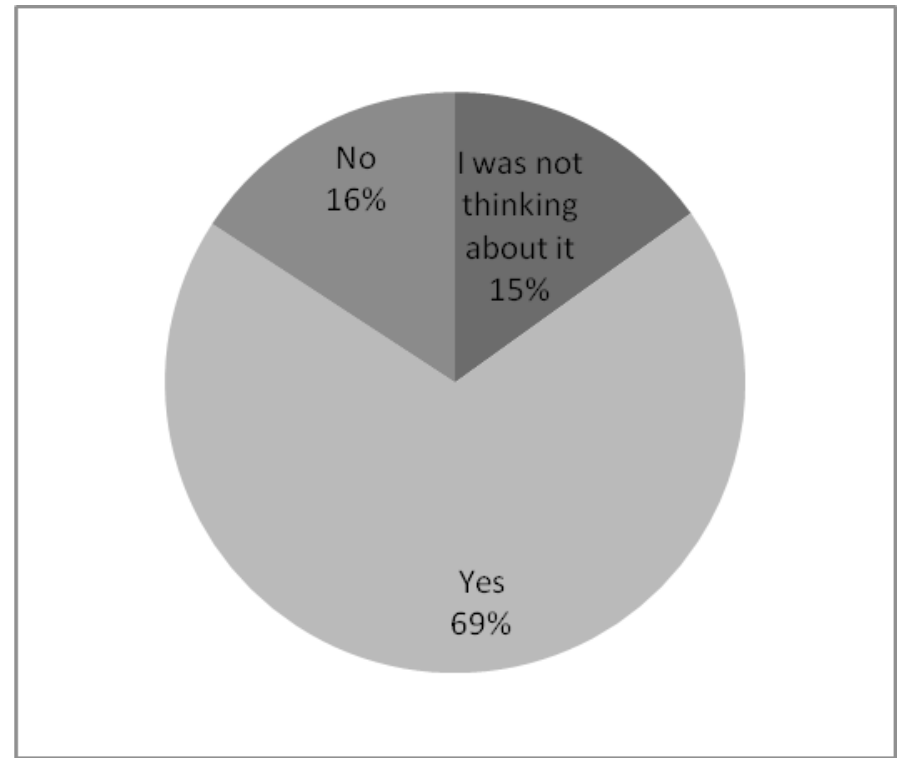

Graph 3. shows that more than two-thirds of respondents believe that proper labelling is an integral part of product quality.

Age group in relation to the question whether proper labelling is an integral part of product quality: $\left(\chi^{2} \mathrm{e}=20,773>\chi^{2} \mathrm{t}(\mathrm{DF}=6\right.$ and 0.05$\left.)=12,592 \Rightarrow \mathrm{p}<0.05 \Rightarrow \mathrm{H1}\right)$. The data show that there is a significant statistical correlation between age group and the attitude that proper labelling is an integral part of product quality. In particular, respondents over 30 believe that proper labelling is an integral part of the product quality.

The level of education in relation to the opinion that proper labelling is an integral part of product quality: $\left(\chi^{2} \mathrm{e}=40,930>\chi^{2} \mathrm{t}(\mathrm{DF}=6\right.$ and 0.05$\left.)=12,592 \Rightarrow \mathrm{p}<0.05=>\mathrm{H} 1\right)$ . From the data it can be noted that there is a significant statistical correlation between the level of education of the respondents and knowledge about whether proper labelling is an integral part of product quality. More educated respondents believe that more than the less educated. 
A dietary regime in relation to the attitude that proper labelling is an integral part of product quality: $\left(\chi^{2} \mathrm{e}=3,794<\chi^{2} \mathrm{t}(\mathrm{DF}=2\right.$ and 0.05$)=5,991 \Rightarrow \mathrm{p}>0.05 \Rightarrow$ H0) . Displayed values are approximately equal according to the dietary regime of the respondents and the attitude that proper labelling is an integral part of product quality, so that the statistics did not detect statistical significance for the two groups of questions.

Age group in relation to confidence in the veracity of label information: $\left(\chi^{2} \mathrm{e}=4,161<\right.$ $\chi^{2} \mathrm{t}(\mathrm{DF}=6$ and 0.05$\left.)=12,592 \Rightarrow \mathrm{p}>0.05=>\mathrm{H} 0\right)$. The data show that the percentages of answers are nearly equal and that the statistics did not detect a significant difference between these two parameters.

The level of education of consumers in relation to confidence in the veracity of label information: $\left(\chi^{2} \mathrm{e}=22,401>\chi^{2} \mathrm{t}(\mathrm{DF}=6\right.$ and 0.05$\left.)=12,592 \Rightarrow \mathrm{p}<0.05 \Rightarrow \mathrm{H1}\right)$. From the data it can be noted that there is a significant statistical correlation between the level of education of respondents and the doubt about the veracity of the label information. Respondents with higher education have more confidence in the veracity of information on labels.

Confidence in the veracity of the label information in relation to the place of residence of the consumer: $\left(\chi^{2} \mathrm{e}=41,383>\chi^{2} \mathrm{t}(\mathrm{DF}=18\right.$ and 0.05$\left.)=28,869=>\mathrm{p}<0.05=>\mathrm{H} 1\right)$. The data show the relation of the doubt about the veracity of the label information which varies according to the place of residence of the respondents.

A dietary regime in relation to confidence in the veracity of label information: $\left(\chi^{2} \mathrm{e}=\right.$ $10,361>\chi^{2} \mathrm{t}(\mathrm{DF}=2$ and 0.05$)=5,991=>\mathrm{p}<0.05=>$ H1. From the data it can be seen that there is a statistical correlation between a dietary regime and the doubt about the veracity of the label information. Respondents who are on a special dietary regime have more confidence in the veracity of information on labels than those on a traditional dietary regime.

Sex of the respondents in relation to the importance of labels on food products: Nearly $70 \%$ of both sexes believe that the label on food products is very important. $\left(\chi^{2} \mathrm{e}=\right.$ $1,512<\chi^{2} \mathrm{t}(\mathrm{DF}=3$ and 0.05$\left.)=7,817=>\mathrm{P}>0.05 \Rightarrow \mathrm{H} 0\right)$. Even here are the values approximately equal according to the sex of the respondents so that the statistics did not detect statistical significance for these two groups of respondents.

Age group and the importance of the label on food products: $\left(\chi^{2} \mathrm{e}=42,291>\chi^{2} \mathrm{t}(\mathrm{DF}\right.$ $=9$ and 0.05$)=16,919 \Rightarrow p<0.05 \Rightarrow$ H1). The data show that there is a significant statistical correlation between age group and knowledge of the importance of the label on food products. Respondents aged over 30 are more likely to consider the label on food products very important compared to younger respondents.

The level of education of consumers in relation to the opinion of the importance of the label on food products: $\left(\chi^{2} \mathrm{e}=54,244>\chi^{2} \mathrm{t}(\mathrm{DF}=9\right.$ and 0.05$)=16,919=>\mathrm{p}<0.05$ $\Rightarrow$ H1). From the data it can be noted that there is a significant statistical correlation between the level of education of respondents and knowledge of how important is the 
label on food products (more educated respondents are more likely to believe that it is important).

The opinion about the importance of the label on food products in relation to the place of residence of the consumer: $\left(\chi^{2} \mathrm{e}=141,466>\chi^{2} \mathrm{t}(\mathrm{DF}=27\right.$ and 0.05$)=40,113=>\mathrm{p}$ $<0.05=>$ H1). From the data it can be seen that the respondents' attitude towards the importance of the label on food products varies among respondents' according to the place of residence.

A dietary regime and opinion about the importance of the label on food products: $\left(\chi^{2} \mathrm{e}\right.$ $=4,560<\chi^{2} \mathrm{t}(\mathrm{DF}=3$ and 0.05$\left.)=7,817=>\mathrm{P}>0.05=>\mathrm{H} 0\right)$. The data show that between a dietary regime and the importance of the label on food products no statistical differences were found in terms of homogeneity of responses to questions.

Frequency of reading the label in relation to the opinion of what the label should contain: $\left(\chi^{2} \mathrm{e}=97,862>\chi^{2} \mathrm{t}(\mathrm{DF}=6\right.$ and 0.05$\left.)=12,592 \Rightarrow \mathrm{p}<0.05=>\mathrm{H} 1\right)$. According to the data it can be seen that the frequency of reading the label and knowledge of what the label should contain stand in a significant statistical correlation. Respondents who always read the label fully know what the label should contain.

Frequency of reading the label and the opinion about whether proper labelling is an integral part of product quality: $\left(\chi^{2} \mathrm{e}=43,772>\chi^{2} \mathrm{t}(\mathrm{DF}=6\right.$ and 0.05$)=12,592 \Rightarrow \mathrm{p}$ $<0.05=>\mathrm{H} 1)$. According to the data it can be seen that the frequency of reading the label and the opinion that proper labelling is an integral part of product quality stand in a significant statistical correlation. Respondents who always read the label believe that proper labelling is an integral part of product quality.

Frequency of reading the label in relation to the confidence in domestic and foreign producers: $\left(\chi^{2} \mathrm{e}=36,478>\chi^{2} \mathrm{t}(\mathrm{DF}=9\right.$ and 0.05$\left.)=16,919 \Rightarrow \mathrm{p}<0.05=>\mathrm{H} 1\right)$. According to the data it can be seen that the frequency of reading the label and the confidence in domestic and foreign producers stand in a significant statistical correlation. Respondents who always and often read the label trust domestic more than foreign producers.

Frequency of reading the label in relation to the confidence in the veracity of the label information: $\left(\chi^{2} \mathrm{e}=48,275>\chi^{2} \mathrm{t}(\mathrm{DF}=6\right.$ and 0.05$\left.)=12,592=>\mathrm{p}<0.05=>\mathrm{H} 1\right)$. According to the data it can be seen that the frequency of reading the label and the confidence in the veracity of the label information stand in a significant statistical correlation.

Frequency of reading the label in relation to the opinion about the importance of the label on food products: $\left(\chi^{2} \mathrm{e}=50,579>\chi^{2} \mathrm{t}(\mathrm{DF}=9\right.$ and 0.05$)=16,919=>\mathrm{p}<0.05$ $=>\mathrm{H} 1)$. According to the data it can be seen that the frequency of reading the label and knowledge of the importance of the label on food products stand in a significant statistical correlation. Respondents who believe that the label on food products is very important always or often read the label. 
Knowledge of the contents of the label in relation to the opinion that proper labelling is an integral part of product quality: $\left(\chi^{2} \mathrm{e}=73,987>\chi^{2} \mathrm{t}(\mathrm{DF}=4\right.$ and 0.05$)=9,488=>p$ $<0.05 \Rightarrow \mathrm{H} 1)$. The data show that there is a significant statistical correlation between the observed values. Respondents who think that they know what the label contains believe that a proper labelling is an integral part of product quality.

Knowledge of the contents of the label in relation to confidence in domestic and foreign producers: $\left(\chi^{2} \mathrm{e}=14,598>\chi^{2} \mathrm{t}(\mathrm{DF}=6\right.$ and 0.05$\left.)=12,592 \Rightarrow \mathrm{p}<0.05=>\mathrm{H} 1\right)$. The data show that there is a significant statistical correlation between the opinion about what the label should contain and the confidence in domestic and foreign producers. Respondents who know what the label should contain trust more domestic producers.

Knowledge of the contents of the label in relation to the confidence in the veracity of the label information: $\left(\boldsymbol{\chi}^{2} \mathrm{e}=35,817>\boldsymbol{\chi}^{2} \mathrm{t}(\mathrm{DF}=4\right.$ and 0.05$\left.)=9,488=>\mathrm{p}<0.05=>\mathrm{H} 1\right)$. The data show that there is a significant statistical correlation between the opinion of what the label should contain and doubt in the veracity of the label information.

Knowledge of the contents of the label in relation to the importance of the label on food products: $\left(\chi^{2} \mathrm{e}=53,970>\chi^{2} \mathrm{t}(\mathrm{DF}=6\right.$ and 0.05$\left.)=12,592=>\mathrm{p}<0.05 \Rightarrow \mathrm{H} 1\right)$. The data show that there is a significant statistical correlation between knowledge of what the label should contain and the importance of the label on food products. Respondents who know what the label should contain believe that it is very important.

Proper labelling in relation to the confidence in domestic and foreign producers: $\left(\chi^{2} \mathrm{e}\right.$ $=38,706>\chi^{2} \mathrm{t}(\mathrm{DF}=6$ and 0.05$\left.)=12,592 \Rightarrow \mathrm{p}<0.05=>\mathrm{H} 1\right)$. The data show that there is a significant statistical correlation between the opinion that proper labelling is an integral part of product quality and confidence in domestic and foreign producers. Respondents who believe that proper labelling is an integral part of product quality have more confidence in domestic producers.

Proper labelling in relation to food products: $\left(\chi^{2} \mathrm{e}=75,866>\chi^{2} \mathrm{t}(\mathrm{DF}=6\right.$ and 0.05$)=$ $12,592=>\mathrm{p}<0.05=>\mathrm{H} 1)$. The data show that there is a significant statistical correlation between the opinion that proper labelling is an integral part of product quality and the importance of the label on food products. Respondents who think that proper labelling is an integral part of product quality, consider the label on food products to be important.

Confidence of consumers - respondents in domestic and foreign producers in relation to the importance of the label on food products: $\left(\chi^{2} \mathrm{e}=34,379>\chi^{2} \mathrm{t}(\mathrm{DF}=9\right.$ and 0.05$)$ $=16,919 \Rightarrow \mathrm{p}<0.05 \Rightarrow \mathrm{H} 1)$. According to these data it can be seen that consumer confidence in relation to the importance of the label on food products are in a significant statistical correlation.

Confidence in the veracity of the label information in relation to the opinion of the importance of the label on food products: $\left(\chi^{2} \mathrm{e}=68,611>\chi^{2} \mathrm{t}(\mathrm{DF}=6\right.$ and 0.05$)=$ $12,592=>\mathrm{p}<0.05=>\mathrm{H} 1)$. From the given data it can be seen that the doubt about the veracity of the label information and the opinion of the importance of the label on food products stand in a significant statistical correlation. Respondents who believe 
in the veracity of the label information consider the label on food products to be very important.

Among the available data on the label respondents most often check: expiry date, then the name of the producer, ingredients, method of preparation and products storage.

\section{Discussion}

The research results can be useful to different participants in the field of consumer rights protection in order to educate consumers about their rights and insist on the compliance with prescribed procedures by the companies which appear on the market.

Consumer protection organizations should consistently insist on informing consumers about their rights as well as ways to fight for those rights. If we take into account that a right carries with it obligation, citizens would be in some way obliged to know the basic contents of the label. Socially responsible behavior of companies implies business activity which is in a function of appreciating and harmonizing interests of different interest groups (stakeholders) of the company, such as consumers, employees, investors, the community (Stanković, Djukić, 2006).

\section{Conclusions}

This research showed that more than half of the respondents always or often read the label. Men and women have a similar relationship to the frequency of reading the label and its contents.

A different study was conducted to assess the use of food labels in making choices on packaged snack and its associated factors among adolescents. A cross-sectional study was conducted in 2012 among 542 Grade 12 students in Sri Lanka. Adolescents' use of labels was assessed by practices (label reading frequency and attention paid to label contents ). The majority $(74.5 \%)$ was frequent ('always' or 'most often') label readers with female predominance $(\mathrm{p}<0.05)$. The majority $(84 \%)$ had good knowledge (obtaining more than the 75(th) percentile mark) on interpreting labels. Although not statistically significant, 'unsatisfactory' label use was higher among males (73\%), purchasing power $(70.4 \%)$ and unhealthy snacking behaviour (73\%). Among the marketing strategies, identifying known brands $(73.2 \%)$ and imported products (75.8 $\%)$ as 'good' products were significantly associated with 'unsatisfactory' label use $(\mathrm{p}<0.05)$. Despite having good knowledge and positive attitudes, food label use is unsatisfactory among adolescents. (Talagala, Arambepola, 2016)

The obtained results also show that more educated consumers are more likely to read the label and know more about its contents. These consumers are more likely to consider the label information an integral part of product quality and have more confidence in the veracity of information on the label.

Results of this research were similar to the results of research conducted by Viola et al. (2016). To evaluate the consumers' knowledge and perception about food-labels a 
brief questionnaire was developed and shared on Facebook between January-March 2016. Most of the participants were young adults with higher education. They declared to read the foodlabels quite often. Despite owing limited knowledge in basic nutrition principles and food-labelling they were generally able to recognize healthier products looking over their nutritional fact tables.

Respondents who know what the label should contain, pay more attention to it.

The conducted research yielded many new insights and opened some new issues for further elaboration and research. Further research should be focused on the following aspects:

- checking the conclusions of this study with a larger sample;

- implementation of continuous research in this area, which would be conducted by the Ministry of Trade and tourism services;

- examination of consumer behavior by other methods other than surveys;

In accordance with the conclusions of Viola et al. (2016), despite the fact that consumers have significant knowledge of the importance of the label and consider it an integral part of product quality, there is room for further improvement in terms of insisting on the consistent implementation of the legislative and legal regulations and other regulatory requirements in companies on the one hand and consumer education on the other.

\section{References}

1. Aydinoglu, N. \& Krishna, A. (2011). Guiltless Gluttony: The Asymmetric Effect of Size Labels on Size Perceptions and Consumption. Journal of Consumer Research, The University of Chicago press, April, Vol. 37 Issue 6, p.1095 -1112, Chicago

2. Božidarević, D. \& Salai, S. (2007). Osnovna pitanja zaštite potrošača u nas. Ekonomske teme, Ekonomski fakultet Niš, p.17, Niš

3. Cvijanović, D., Simonović, Z., Mihailović, B. (2011). Tržišta i ciljevi najnovijih reformi agrarne i regionalne politike Evropske Unije. Ekonomika poljoprivrede, Naučno društvo agrarnih ekonomista Balkana, Institut za ekonomiku poljoprivrede Beograd, vol. 58, no. 3, pp. 359-371, Beograd

4. Ćemalović, U. (2016). Usklađivanje pravnog sistema Srbije sa pravnim tekovinama Evropske Unije - slučaj životne sredine. Ekonomika poljoprivrede, Naučno društvo agrarnih ekonomista Balkana, Institut za ekonomiku poljoprivrede Beograd, No. 3, pp.891-904, Beograd

5. Hanić, H. (2002). Istraživanje marketinga i marketing informacioni sistem. Ekonomski fakultet Beograd, p.59-63

6. Hieke, S., Newman, C. (2015). The Effects of Nutrition Label Comparison Baselines on Consumers' Food Choices. Journal of Consumer Affairs, Cornell University, Fall2015, Vol. 49 Issue 3, p. 613-626. USA 
7. Larceneux, F. Benoit Moreau, F. \& Renaudin, V. (2012). Why Might Organic Labels Fail to Influence Consumer Choices? Marginal Labelling and Brand Equity Effects. Journal of Consumer Policy, Springer, Mar, Vol. 35 Issue 1, p.85 -104, USA

8. Maričić, B. (1999). Ponašanje potrošača. Savremena administracija: Beograd, p. 380

9. Paul H. (2010). How Mainstream Consumers Think about Consumer Rights and Responsibilities. Journal of Consumer Research, The University of Chicago press, Vol. 37, December, p.670 -687, Chicago

10. Payne, H. (1947). Standardized description, a form of specification labeling. Journal of Marketing, American Marketing Association, Oct, Vol. 12 Issue 2, p.234 -241, USA

11. Simonović, D. (2006). Komentar Zakona o zaštiti potrošača. Gorapres: Zemun, p. 9-14

12. Official Gazette of RS No. 53/2010, Belgrade

13. Official Gazette RS No. 41/2009. Law on Food Safety, Belgrade

14. Official Gazette RS No. 85/2013 and No. 101/2013. Rules on food description, labeling and promoting, Belgrade

15. Official Gazette RS No. 43/2013 and No.16/2016. Rules on previously packaged products, Belgrade

16. Regulation (EC) No. 1924/2006 on nutrition and health claims made on foods.

17. Regulation (EC) $983 / 2009$ on the authorisation and refusal of authorisation of certain health claims made on food and referring to the reduction of disease risk and to chidren's devolopment and health.

18. Regulation (EU) No. 432/2012 establishing a list of permitted health claims made on foods, other than those referring to the reduction of disease risk and to children's development and health.

19. Regulation (EU) No. 1169/2011 on the provision of food information to consumers.

20. Stanković, Lj. \& Djukić S. (2006). Unapredjenje konkurentske prednosti putem društvene odgovornosti preduzeća. Ekonomske teme, Ekonomski fakultet Niš, 1-2, p. $233-245, \mathrm{Ni} \breve{s}$

21. Talagala, I., Arambepola, C. (2016). Use of food labels by adolescents to make healthier choices on snacks: a cross-sectional study from Sri Lanka. BMC Public Health, Bio Med Central, 8/8/2016, Vol. 16 Issue 1, p1-11. ISSN 1471-2458

22. The weight and measures (Packaged goods) Regulation SI 2006/659.

23. Trandafilović, I. (2008). Uticaj zemlje porekla na izbor marke proizvoda. doktorska disertacija. Fakultet za menadžment: Zaječar, p.174

24. Viola, G. C. V., Bianchi, F., Croce, E., Ceretti, E. (2016). Are food labels effective as a means of health prevention? Journal of Public Health Research, PAGEPress Vol. 5 Issue 3, p139-142, Pavia, Italy 
25. Vujović, S., Spajić, J., Vukosavljević, D., (2011). Anatomizovanje turističke tražnje u svetlu ekonomskih zakonitosti, fenomena, efekata i paradoksa u potrošnji. Ekonomika Poljoprivrede, Naučno društvo agrarnih ekonomista Balkana, Institut za ekonomiku poljoprivrede Beograd, (58) 4, pp. 563-576. Beograd

26. U.S. Department of Health and Human Services - Food and Drug Administration and the Center for Food Safety and Applied Nutrition (2013). A Food Labeling Guide, January, USA

\title{
ISTRAŽIVANJE NAVIKA POTROŠAČA U KORIŠĆENJU DEKLARACIJE NA PREHRAMBENIM PROIZVODIMA
}

\author{
Igor Trandafilović4, Zoran Miloševićc ${ }^{5}$ Slavoljub Vujovićc
}

\begin{abstract}
Summary
U radu je prezentovano istraživanje poznavanja značaja i sadržine deklaracije na prehrambenom proizvodu, kao i odnos prema podacima na deklaraciji. U istraživanju su korišćeni Pirsonov hi kvadrat test homogenosti $i$ Pirsonov hi kvadrat test nezavisnosti. Uzorak je sačinjen od 598 ispitanika iz 10 gradova Republike Srbije. Rezultati pokazuju da više od polovine ispitanika uvek ili često čita deklaraciju. Muškarci $i$ žene imaju sličan odnos prema učestalosti čitanja deklaracije i njenom sadržaju. Ispitanici sa specijalnim režimom ishrane češće čitaju podatke na deklaraciji od onih sa klasičnim režimom. Obrazovaniji potrošači češće čitaju deklaraciju i više znaju o njenom sadržaju. Ispitanici koji znaju šta deklaracija treba da sadrži češće smatraju da je jako važna.
\end{abstract}

Ključne reči: prehrambeni proizvodi, ponašanje potrošača, deklaracija na proizvodu, konzumerizam

4 dr Igor Trandafilović, vanredni profesor, Univerzitet Džon Nezbit Beograd, Fakultet za menadžment Zaječar, Kraljevica bb, tranfi@ptt.rs, +381600599598

5 dr Zoran Milošević, generalni direktor JP Pijaca Leskovac, Kralja Petra I bb, miloseviczoran393@gmail.com, +381648973911

6 dr Slavoljub Vujović, viši naučni saradnik, Ekonomski institut Beograd, Kralja Milana 16; kelovic1967@yahoo.com, +38163365101

EP 2018 (65) 1 (33-47) 